Article

\title{
In the Shadow of Public Opinion: The European Parliament, Civil Society Organizations, and the Politicization of Trilogues
}

\author{
Justin Greenwood $^{1, *}$ and Christilla Roederer-Rynning ${ }^{2}$ \\ ${ }^{1}$ Aberdeen Business School, Robert Gordon University, Aberdeen, AB10 7QE, UK; E-Mail: j.greenwood@rgu.ac.uk \\ 2 Department of Political Science and Public Management, University of Southern Denmark, 5230 Odense M, Denmark; \\ E-Mail:crr@sam.sdu.dk
}

* Corresponding author

Submitted: 4 April 2019 | Accepted: 19 June 2019 | Published: 27 September 2019

\begin{abstract}
This article examines the relations between the European Parliament (EP) and civil society organizations (CSOs) in the EU's legislative process. It focuses specifically on legislative trilogues, an informal institution bringing together the representatives of the EP, Council, and Commission in a secluded setting to conclude legislative agreements. Trilogues have become the modus operandi and an absolutely pivotal part of the EU law-making process: they are where the deals are made. While secluded decision-making offers plenty of opportunities for EU institutions to depoliticize law-making, we argue that trilogues have become politicized, partly from the relationship between the EP and CSOs. We flesh out this argument on the basis of insights from the politicization and the historical institutionalist literatures, advance two ideal types of trilogue politics, and explore these types on the basis of a preliminary examination of a comprehensive interview material.
\end{abstract}

\section{Keywords}

civil society organisations; European Parliament; institutionalism; law-making; legislative process; politicisation; trilogues

\section{Issue}

This article is part of the issue "Out of the Shadows, Into the Limelight: Parliaments and Politicisation", edited by Christine Neuhold (Maastricht University, The Netherlands) and Guri Rosén (University of Oslo, Norway).

(C) 2019 by the authors; licensee Cogitatio (Lisbon, Portugal). This article is licensed under a Creative Commons Attribution 4.0 International License (CC BY).

\section{Introduction}

'Trilogues' are the EU's word for an in-camera, three-way negotiation between the main legislative institutions, the European Parliament (EP), Council of Ministers, and Commission, aimed at reaching legislative agreements. They have no references in the EU treaties, but a substantial majority of EU legislation go to trilogues (Brandsma, 2015), mostly resulting in inter-institutional first reading (or early-second) agreement (EP, 2017a). While this form of policy-making has facilitated EU law-making, it potentially achieves this by de-politicising issues, given the secluded setting, the premium on bargaining, and the importance of technical negotiations (Stie, 2012).

Even so, trilogues have been the object of a growing public debate, fuelled in particular by discontentment in the EP and negative press coverage (EU Observer, 2014; International New York Times, 2014), and leading to the involvement of the European Ombudsman and the Court of Justice of the EU (CJEU). The European Ombudsman and the CJEU have now made it clear that trilogues are a pivotal part of the law-making process of the EU-it is 'where deals are made'-subject to the same transparency requirements that the other phases of the EU law-making process. Thus, willy-nilly, trilogues have entered a new phase of their institutional life cycle, characterized by the end of the permissive consensus and the emergence of restraining dissensus (to paraphrase Hooghe \& Marks, 2009).

In this article, we examine how trilogues have become a politicized law-making institution. Our premise is that the contemporary debate on the transparency of tri- 
logues represents the tip of the iceberg of a more gradual process of politicization, initiated from within. Our working hypothesis is that the EP is the main driver of this process, politicizing an otherwise closed and rather technical set of negotiations by relying on a broad range of civil society organizations (CSO), although especially nongovernmental organizations (NGOs) ${ }^{1}$. Given the early state of research on trilogues, our focus is on sketching out a theoretical argument through which to grasp the politicization of trilogues, and to outline very preliminary evidence.

Theoretically, we develop a perspective combining insights from recent works on the politicization of European integration and from historical institutionalism. While the politicization literature is rapidly becoming the main frame of reference on this topic in EU affairs and can help us conceptualize politicization as an EU phenomenon, we need to supplement its overriding focus on the public sphere with an account of politicization from within (institutions). Historical institutionalism is well-suited to do this because it is based on an understanding of institutions as instantiations of power and the result of political compromises, and because it offers a complementary understanding of change as an endogenous process.

Empirically, the difficulty of studying trilogues is to access data, given the closed and rather informal character of this phenomenon. Barring the option of participant observation, to which we did not have access, alternatives are to rely on content analysis of legislation (Laloux \& Delreux, 2018) or on interviews with EU practitioners. We chose the latter research strategy given our interest in probing the relationship between the EP and CSOs. The data upon which we draw in this study are part of a broader dataset of more than 87 interviews with EU practitioners, collected for the purpose of a larger research project focusing on information flows between EU lawmakers and CSOs in trilogues. The interviewees are both trilogue 'insiders' and 'outsiders', where insiders are those who participated in trilogues, or are involved in institutional preparation for trilogues, whereas outsiders are those who have no official access to the trilogue process.

In this article, we focus on a sub-set of interviews (interviews with CSOs) and provide insights from an exploratory foray into the empirical material. These interviews help us flesh out ideal types of relationships between the EP and CSOs, arrived at through a distillation and extrapolations of the findings of the EU lobbying literature.

\section{The Case for Studying Trilogue Politicization}

The role of CSOs in the EU political system is welldocumented. A range of CSOs, comprising producer organisations and NGOs: supply EU institutions with technical (Warleigh, 2000) and political information; act as political supporters and messengers where there is common cause; aggregate and articulate interests (Albareda \& Braun, 2019); represent concentrated interest constituencies or act as a proxy for a diffuse and often disengaged civil society (Greenwood, 2017; Klüver, 2013; Kohler-Koch \& Quittkat, 2013). Their role is particularly important in EU policymaking because much EU legislation is regulatory in nature, requiring extensive technical information, placing a premium on those able to supply it in a convenient format. In the EU, it has long been recognised that access to every-day policymaking is dependent upon the supply of information (Chalmers, 2019; Klüver, Braun, \& Beyers, 2015; Mazey \& Richardson, 1993). Strikingly, we know very little about the role of CSOs in trilogues. The bulk of the literature has focused on the other parts of the EU policy cycle: agenda-setting; policy formulation; and implementation. By contrast, the decision-making phase remains understudied, and the trilogue phase is a blind spot in the research agenda.

Yet, there is no reason why the flows of information between EU lawmakers and organized interests should stop during the highly pivotal trilogue phase. Trilogues typically last for a six-month period and involve an average of three 'political' level inter-institutional meetings (Brandsma, 2015, 2018), during which time a range of lobbyists seek information about the progress of discussions, and, where possible, to influence the detail of proposals which challenge their position. A notable exception is the case study by Andlovic and Lehmann (2014). In this study of aviation emissions trading, the authors provide evidence of industry group lobbying of the EP ('individual Members of the European Parliament [MEPs] from certain member states, supposedly most affected by the implementation of the directive'), resulting in and that, in turn, 'these MEPs, having detailed knowledge of the directive, were instrumental in the last stages of the trilogues' (Andlovic \& Lehmann, 2014, p. 813; our emphasis). Other studies have likewise suggested that trilogues tend to privilege producer interests at the expense of other types of interests (Burns, Carter, Davies, \& Worsfold, 2013; Dionigi \& Koop, 2017). But we know remarkably little about how CSOs connect with the trilogue process, and whether systematic biases are built into trilogues.

It is thus time we addressed this lacuna more systematically. We propose to do so by developing a framework of understanding combining insights from the EU-related politicization literature and from the more general comparative politics literature on historical institutionalism.

\section{Trilogue Politicization: A Historical Institutionalist Perspective}

There has been a surge in academic interest in the politicization of European integration. In 2009, Hooghe and Marks argued that European integration had entered a new phase at the turn of the 1990s, as a result of a deep-

\footnotetext{
$\overline{1}$ In this article, we draw a distinction between two types of CSOs: producer associations and NGOs.
} 
ening of the integration process (i.e., the establishment of the EU in the Treaty of Maastricht). 'Permissive consensus' was paving the way to 'restraining dissensus' as European integration became a more salient issue in domestic politics and the object of growing partisan controversies (Hooghe \& Marks, 2009). The crises of the 2010s, the rise of Euroskepticism, and the Brexit referendum have shown that European integration is no longer 'for elites only' (Baglioni \& Hurrelmann, 2016). Broader European publics mobilize on EU issues in ways that can have important consequences.

From the rapidly growing literature on politicization, two main insights are relevant here. The first concerns the definition of politicization as an observable phenomenon comprising three main dimensions: '1) the growing salience of European governance...2) a polarisation of opinion, and 3) an expansion of actors and audiences engaged in monitoring EU affairs' (De Wilde, Leupold, \& Schmidtke, 2016). The second concerns the extraordinary differentiated character of politicization. Politicization takes many shapes and forms, it has many objects, and it is driven by a range of factors rather than, as originally assumed, the universal manifestation of the deepening of European integration and transfer of authority to the EU (De Wilde \& Zürn, 2012). Accounts of politicization must therefore start with a careful specification of the phenomenon under study, not least the arena in which it is observed. Baglioni and Hurrelmann (2016, p. 106), for example, propose a simple distinction between three arenas of politicization: a citizen arena, where 'laypeople engage in politics'; an intermediary arena, where we find participants with a professional interest in politics (political parties, interest groups, medias); and an institutional arena, which is at 'the core' of the political system and is populated by politicians from, e.g., the EP and national parliaments.

Drawing on this first stand of scholarship, we can specify the conceptual underpinnings of our research question as follows. Paraphrasing De Wilde et al. (2016), by politicization of trilogues, we mean the process by which actors in the trilogue negotiations highlight the salience of individual issues, create controversies, or expand the range of actors and audiences engaged in monitoring EU affairs. Our inquiry is located squarely within the institutional arena, in fact at the heart of the machine-room of EU law-making where deals are made, and where we can expect EU institutions to revert to depoliticization strategies. Indeed we know that:

When a policy decision point approaches, but clashes between rival advocacy coalitions cause impasse, the EU's natural propensity is to depoliticize issues and 'push' them back to the sub-systematic level [of expert committees and professional networks] for quiet resolution. (Peterson, 2001, p. 309)

While the politicization perspective helps us pinpoint the pivotal significance of trilogue decision-making in light of EU institutions' propensity to depoliticize issues, trilogues also bring us to the outer limits of what this perspective can help us make sense of. Indeed, how can it possibly make sense to talk about issue saliency in trilogue negotiations, when a proper public is missing? And how can it possibly make sense to talk about actor and audience expansion in trilogues when these negotiations are closed and only involve a fixed set of institutional actors?

In order to make sense of these questions, we must understand what institutions are and how intrinsic conflict is to their formation and functioning: in other words, we need to retrieve a few basic insights from historical institutionalism. According to historical institutionalism, institutions are more or less solidified power struggles (Mahoney \& Thelen, 2010; Waylen, 2014). They emerge from power struggles, and are nothing else than political compromises that make orderly politics possible. But unlike other political compromises, for example on policy issues, the political compromises creating institutions are more structural insofar as they set the parameters for a whole range of subsequent (policy) decisions (Moe, 2005). Besides establishing an intimate link between institutions and power, historical institutionalism also makes it possible to understand change, and therefore also politicization. The important insight in this respect is that change is endogenous to institutions, because institutions are never 'cohesive and equilibrating' and therefore 'power, contestation and distributional issues [must be] at the center' of the analysis (Waylen, 2014, p. 216).

Viewing trilogues as an institution, we argue that a key conflict enabling this institution to emerge in the first place was a power conflict between Council and the EP. This conflict has been rooted in the redistribution of power between the EP and Council, as illustrated by the long-term constitutional empowerment of the EP (Rittberger \& Schimmelfennig, 2006). In the early years of co-decision, Council soon learned that it could not 'just' ignore the EP's legislative position by reintroducing its common position after failure to reach an agreement in conciliation (Shackleton, 2000; Shackleton \& Raunio, 2003). Under the Council's impulse, trilogues emerged in 1994 as a means of paving the way for a more predictable process by building confidence between Council and the EP. Since then, they have been defined by the clashing narratives of efficiency (Council) on the one hand, and institutional and partisan empowerment (EP) on the other hand. Contrary to the Council narrative on trilogues, most MEPs today see trilogue secrecy and seclusion as a way to politicize-not depoliticize-EU lawmaking by bringing salient issues to bear at the heart of the law-making machine room (Roederer-Rynning \& Greenwood, 2019). This narrative builds upon an EP selfunderstanding as the 'tribune of the people', in contrast to views of the Council as the 'creature of the member states'. The result of this clash is that trilogues are an inherently unstable, or dynamic, institution, containing in 
its very heart the seeds of politicization. Below, we sketch out two main potential paths ensuing from this unstable power game and meeting of cultures between the EP and Council in trilogues. Before we do this, however, we trace how the EP has sought to bring secluded trilogues more into line with established standards of democratic lawmaking. Trilogue reform in the EP shows that, while the EP is a force of change, it is also affected by its own internal dissensions.

\section{The EP and Trilogue Reform: Internal Dissension and Reform Push}

Figure 1 captures the picture of relief and common endeavour as a deal is reached in trilogue negotiations following intensive (sometimes all-night) negotiations, with senior figures in attendance from each of the EU institutions.

In reality, the team negotiating for the EP with the Council of Ministers will have a small number of 'red lines', generally salient issues with public recognition, whilst willing to give way to the Council on technical details of legislative files which are difficult to make accessible for public debate (Greenwood \& RoedererRynning, 2014).

Given its directly elected mandate, the EP has been the most sensitive of the three EU institutions to the implications of trilogues for its democratic legitimacy. For this reason, it has developed a series of measures in its Rules of Procedure (RoPs) aimed at the oversight of arrangements. RoPs are relatively politicised, and the result of extensive deliberation in the EP. Current RoP allow for four levels of oversight in trilogues. First, as regards trilogues, the Committee's position on a legislative file is always public. Secondly, plenary has the ability to overturn a Committee's recommendation to open trilogue negotiations, a procedure triggered in the first instance by just one-tenth of members. Third, there is pluralisation of participation, in that there is a negotiating team for the EP comprising the Rapporteur and Shadow Rapporteurs from the different political parties, with the Committee Chair or Vice-Chair present, and political party advisors in attendance at trilogue meetings. These attendees ensure that the EP always has a numerical majority in meetings, and the reforms have collectively given political trilogues the semblance of formality with echoes of the now (almost) defunct Conciliation Committees (Figure 2).

A fourth level of oversight provided for by the RoP is that the team must report back to Committee on the progress of trilogue negotiations.

These rules allow for some degree of publicity throughout the trilogue process, but are not without problems. One first problem is linked to implementation of these rules. In practice, it turns out for example that the report back in Commission is often perfunctory or non-existent (Brandsma, 2018). Another problem is that the final stage where the Committee presents its position to plenary is often a fait accompli, with plenary reluctant to intervene in what is presented as carefully crafted and fragile agreements made between the knowledgeable negotiating team and the other EU institutions, which in turn are presented as having limited room for manoeuvre. Finally, lack of access to key trilogue documents has generated ongoing internal rumblings in the $E P$, which resulted in a keynote lawsuit against the EP, and was undoubtedly a factor in the Ombudsman's decision to open an own-initiative inquiry into the transparency of trilogues.

In 2018, the ruling of the CJEU on the De Capitani case (Case T-540/15) annulled a decision of the EP to refuse to grant Mr Emilio De Capitani, a retired former EP administrator, full access to trilogue documents. The EU institutions had argued that release of the doc-

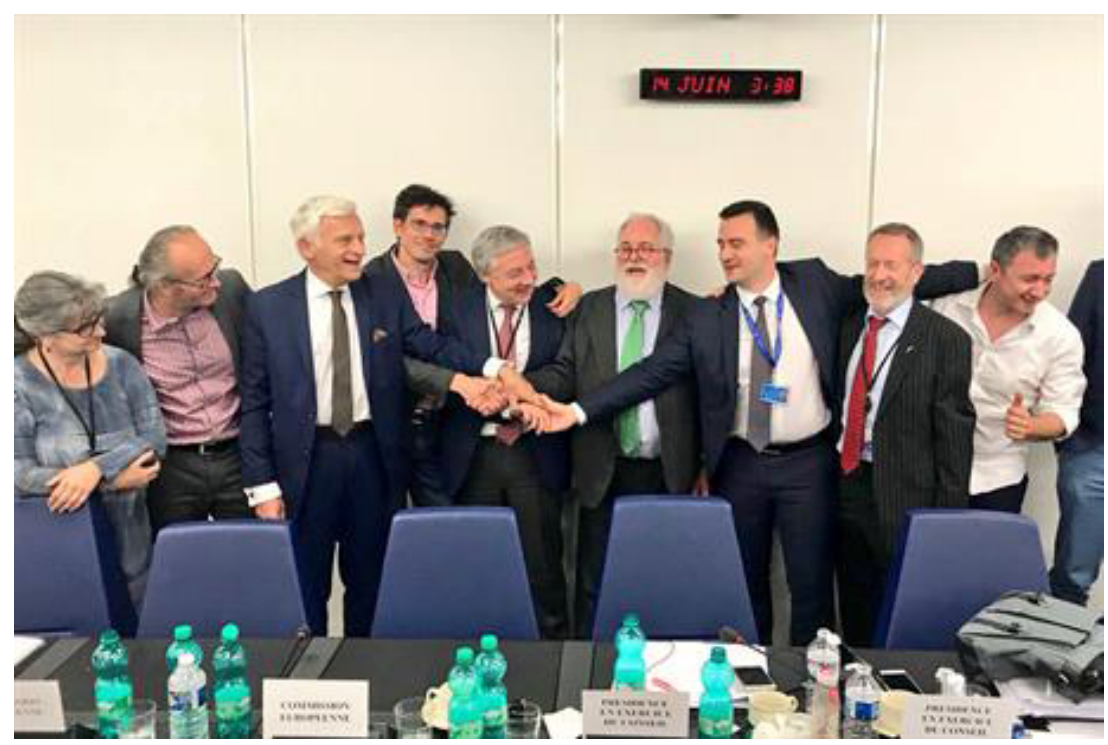

Figure 1. Mission accomplished: Agreement at the end of a trilogue meeting. Source: Weston (2018). 


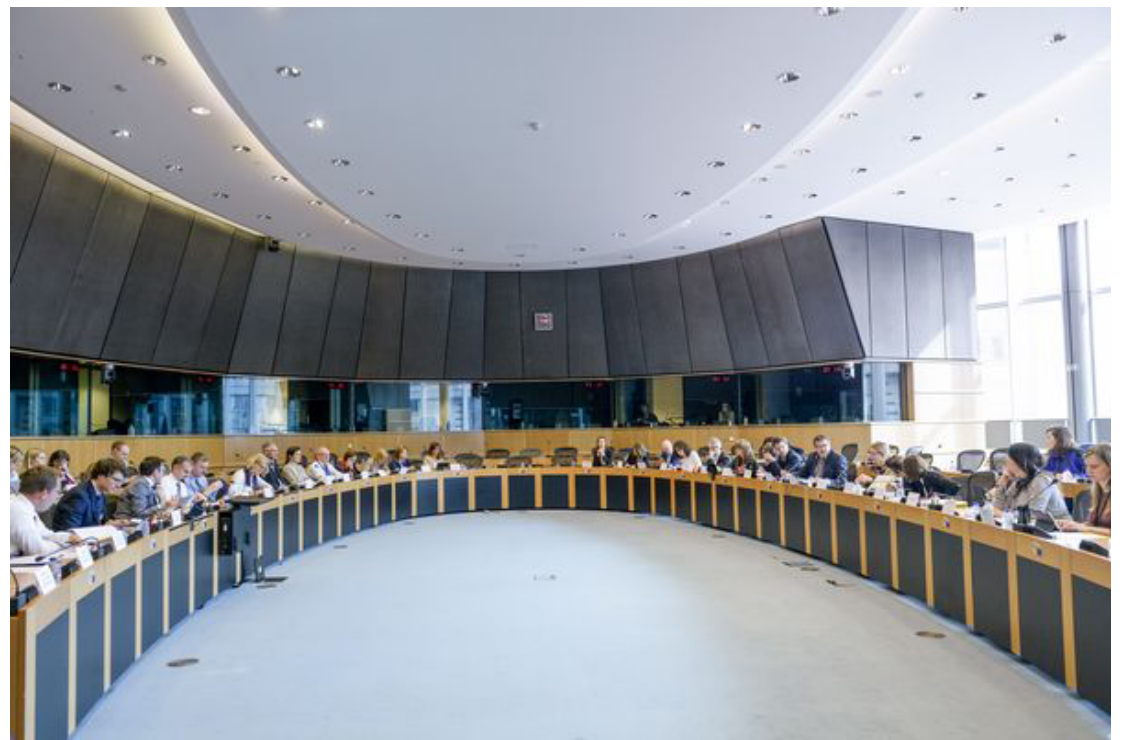

Figure 2. A trilogue in process. Source: EP (2017b).

uments were covered by an exception in the Access to Documents Regulation (1049/2001) involving internal preparatory documents, whereas the Court found that the EU institutions' very restrictive interpretation of the principles of publicity and transparency in trilogues, amounted to a 'general presumption of non-disclosure'. Moreover, the Court recognised the position of trilogues as a regular part of the legislative procedure, something the Council had disputed, and therefore subject to Article 12 of Regulation 10/2001 which provides for proactive publication in a register of documents (Emiliano De Capitani v. European Parliament, 2018; RoedererRynning \& Greenwood, 2019; Interview 87). Similarly, the Ombudsman framed a critical decision about trilogues (European Ombudsman, 2016) around the citizens' right to participate in EU public policy making, specified in Articles 10 (3) and 11 (1-3) of the Treaty on EU, and Article 15(1) of the Treaty on Functioning of the EU (TFEU), noting the pre-requisite of transparency to facilitate participation. The Ombudsman, in her report, had asked the institutions to publish a list of documents, if not proactively (the preferred option among trilogue activists) at least retrospectively, and to construct a joint trilogue database.

Both the keynote De Capitani ruling and the Ombudsman's report seem set to change the trilogue institutions. At the time of writing, the institutions have yet to change practice, but the direction of travel towards more transparency in trilogues is clearly founded in the decisions of the General Court and the Ombudsman.

\section{In the 'Shadow of Public Opinion': Two Types of Trilogue Politics}

Based on the above conceptualization of trilogue politicization and a cursory overview of how the EP has pushed for trilogue reform, we can now elaborate two ideal-types of trilogue politics. These trilogue types synthesize the insights of the abundant literature on EU lobbying, within the above delineated framework of trilogue politicization.

\subsection{The EP as a 'Responsive' Legislator}

The first type of trilogue politics corresponds to situations where the EP uses its participation in the trilogue process to champion diffuse interests and thus pluralize, or in the terminology adopted in this article politicize, the deal-making phase. Given its popular mandate, the EP has traditionally been cast as the most 'responsive' of all three policy-making institutions to NGOs which claim to articulate 'diffuse' or public interests (Earnshaw \& Judge, 2011; Judge, 1992; Pollack, 1997). The ability of social movements and NGOs to politicise issues and apparently turn the position of the EP is captured in the literature by case studies (Dür \& Mateo, 2014). In turn, we know that the EP has stepped up efforts at producing policy expertise, as a part of its broader strategy to develop institutional autonomy from the Commission and Council. It has also helped to stimulate the formation of NGOs (such as 'Finance Watch') where no counterweight to sectoral business interests exist, in an attempt to balance the supply of information. And for highly salient issues the EP still adopts public facing positions, reflecting its appetite for issues that are highly politicised. The orientation of the EP towards CSOs and particular types of CSOs may nevertheless vary by committee and their role in a particular legislative file (Brandsma, 2015; Dionigi, 2019; Ripoll Servent, 2018).

While the literature does not deal with trilogues specifically but co-decision in general, we can expect to find close and mutually reinforcing ties between the EP and NGOs in trilogues. NGOs find in the EP an ally ready to politicize trilogues. In return, the EP can assert itself 
through the 'noisy' politics of NGOs. Trilogues offer the EP negotiating team a possibility to extract concessions from a usually more conservative Council by politicizing the negotiations. The EP has two main levers at its disposal: 1) trilogues give all EP groups a seat in the negotiations, which maximizes the chance that a plurality of (diffuse) interests are represented and informed along the way; 2) the EP negotiating team can use 'the shadow of public opinion' as a source of pressure during the trilogue negotiations. As one EP participant put it, 'it boils down to public pressure. If they had said, it's not important, then we could have scandalized' (interview quote, as cited in Greenwood \& Roederer-Rynning, 2014, p. 334).

\subsection{The EP as a 'Responsible' Legislator}

In the second type of trilogue politics, the EP has become more 'responsible' with the acquisition of legislative powers, which has prompted it to moderate its policy claims and expectations. There are two main potential explanations. One is that, with increased legislative powers, the EP has become more 'realistic' in its demands because it becomes more attentive to the political implications of its preferences and more sensitive to the political realities at hand (Jacqué, 2009; Rasmussen, 2014). Another is that legislative empowerment has made the EP much more dependent on fine-grained expertise. In turn, this is expected to give business interests greater political clout in the EP (Burson-Marsteller, 2009; Coen \& Katsaitis, 2019; Dür \& de Bièvre, 2007). We call this thesis the 'mirror thesis' to highlight the idea that a more powerful EP, according to this thesis, increasingly 'reflects itself' in the Council, adopting Council standards of appropriateness and procedural norms (need to compromise, need to have a realistic view of the problem at hand, need to 'behave responsibly') at the expense of its own policy preferences (Ripoll Servent, 2013). What legislative empowerment does is thus to turn the EP as a second Council.

While the literature focuses on co-decision in general, we can hypothesize that trilogues tend to place the $E P$ in a situation of an even greater dependence-rather than increased bargaining power-for two reasons. First, the acceleration of the pace of the negotiation makes it critical for the EP to have access to reliable expertise. The more the negotiations advance, the more critical the need for swift and fine-grained expertise. Second, the fact that the chief implementation expertise is located within the Council (member state bureaucracies) makes the EP vulnerable to Council criticisms on behalf of the 'irresponsible' or 'unrealistic' character of EP demands as the tedious process of working systematically through the EP amendments begins in trilogues. Council comes to trilogues after a long phase of internal work, during which the member states together with the Commission in reality fine-combed the legislative proposal of the Commission and the proposed Council amendments with a view to discussing their added value and technical feasi- bility. The EP comes to trilogues lacking not only internal expertise on policy implementation but also lacking the intensive Commission scrutiny of its proposed amendments. Trilogues are thus, a 'reality check' for the EP, literally as well as figuratively. Consequently, this scenario implies that trilogues inaugurate a phase during which NGOs are structurally disadvantaged relative to other types of CSOs, because: 1) they will be perceived as unhelpful allies, politicizing negotiations at a time when legislators are focused on compromise and de-politicization; and 2) they are less likely to provide the kind of swift and detailed expertise that is crucially needed in the final phases of the trilogue negotiations.

\section{Preliminary Insights}

One of the key problems with trilogue research is the difficulty to find reliable and accessible data. This problem is naturally tied to the secluded and still informal nature of the negotiations. Ideally, we would have carried out participant observation, but since this option was not open, we settled for interviews with EU lawmakers. Long past are the days when interviews were seen as a second best in qualitative research. Interviews can give a multiplicity of deep insights into a process, which some ethnographers have captured by the term 'ethnographic interviews' (Rubow, 2003; Spradley, 1979). Drawing on this method, which we describe elsewhere, we undertook 87 interviews between June 2017 and January 2019 with the full range of CSOs (producer organisations, consultancies, NGOs), Permanent Representations (PERMREP), MEPs, their assistants, political party advisors in the EP, and a former member of the EP secretariat, aimed at investigating the role of CSOs in trilogues (Table 1 ). In this article, we report preliminary insights into trilogue politicization by drawing on the sub-set of interviews with $\mathrm{CSO}$, and discuss potential links with the two ideal-type models of trilogue politics. Four observations strike us.

\subsection{Information as Currency of Power}

Interviews highlighted the (well-known) fact that information is the currency of power in Brussels. One of the producer participants in our study, a trade union, repeated many times during the course of interview that 'You can always access the information you need if you have an office in Brussels' (Interview 2). An office provides the means to establish and maintain regular networks, but also the opportunity to develop expertise as to the stage of the legislative process from where information can be accessed. One MEPs Assistant reflected that:

Those with the best contacts get the most information, and information is power...those with the staff can find the information in a public database, but where information is not published then it is down to contactsthis is the stereotype of the EU. There needs to be a 
Table 1. Interviewees.

\begin{tabular}{|c|c|c|c|}
\hline \multicolumn{2}{|l|}{ Trilogue insiders } & \multicolumn{2}{|l|}{ Trilogue outsiders } \\
\hline PERMREP & 12 & Civil Society Organisations & $38 *$ \\
\hline Large countries & 2 & NGOs & \\
\hline Medium countries & 7 & Trade Unions & $16(15)$ \\
\hline \multirow[t]{2}{*}{ Small countries } & 3 & Producer Associations & $2(1)$ \\
\hline & & & 20 (19) \\
\hline EP: & 30 & Other & 6 \\
\hline MEPs (5 parties, 7 committees) & 13 & Public Affairs Consultancies & 3 \\
\hline Party Advisors (same affiliations as MEPs) & 11 & European Ombudsman's office & \\
\hline \multirow[t]{2}{*}{ Assistants to MEPs } & 4 & Territorial governmental representative organization & 1 \\
\hline & 2 & Mr Emilio De Capitani & 1 \\
\hline Total & 42 & & 45 \\
\hline
\end{tabular}

Note: ${ }^{*}$ Number of CSOs at EU level in parenthesis.

one-stop shop for information where it is published. Info needs to be given to everyone. (Interview 37)

\subsection{Written Information Sources}

A producer association referred to accessing the 'outcome of proceedings', a kind of (lesser known) unofficial minutes from Council Working Parties (Interview 63). An NGO also referred to these, emphasising a common pool of expertise among professionalised civil society organisations, whether producer or NGO (Interview 44). The Council register was seen as the best tool: 'I check every morning the Council register, and go through line-by-line the documents that are important for us' (Interview 45). Some producer related associations received some limited trilogue related logistical information (such as the announcement of a forthcoming trilogue) through specialised subscription sources such as Dods, One Policy Place and EU Issue Tracker, as well as generalised media sources, though subscription services do not extend to obtaining trilogue documents or political information (Interview 12). Among the generalised media sources, Politico was seen as heralding something of a revolution since its arrival on the Brussels scene in 2014, though having the effect of 'making PERMREPS go back into their shell' (Interview 70). Of these written sources, only the Council register is publicly available-all others have to be accessed through one form of contacts with trilogue insiders. Trilogue documents were seen as particularly difficult to obtain during the latter stages of a trilogue, irrespective of the type of civil society organisation, because of the speed at which the decision-making process moved at that stage (Interview 68).

\subsection{Information Supply and Demand}

The view as to the availability of information for those with a Brussels office was generally shared across producer organizations as well as NGOs, particularly among the well-staffed environmental NGOs, but also among many of the smaller NGOs (Interview 44). Nonetheless, there was almost universal agreement among civil society organisations that information could be obtained by exchanging information or value added analysis, including counter arguments. These factors generally relate to the supply of information, but demand for information from EU institutions was also a key factor. A PERMREP from a smaller country confided that 'there are domains where we don't have great expertise, such as Audio Visual and IT, and our lack of expertise in some subjects makes us attractive targets for lobbying' (Interview 12). Access to information about trilogues was generally available through the return favour of providing value added analysis (Interview 51), and political and technical information, and where the CSO was going in the same direction of travel as the institutional actor in question (Interview 74). The ability to acquire information quickly enough in order to make an intervention during the course of trilogues was seen as related to the ability to provide sufficient added value to a contact (Interview 51).

\subsection{Dislike of Trilogue Un-Transparency}

There was a common dislike of the lack of transparency of trilogues and the need to obtain information about legislative progress through informal sources, indicating the limited extent to which these sources could deliver information in sufficient time to be able to follow the trilogue process in full in order to make interventions; if there is dissatisfaction about the supply of information, it indicates that organisations don't have sufficient advantage to be able to keep it all to themselves. This across the board dislike was also evident in the responses to the European Ombudsman's public consultation on trilogues (European Ombudsman, 2016).

\subsection{CSOs as Emissaries}

Not infrequently, NGOs reported being agents of political communication between the institutions; for one NGO, 'it happens all the time that we are political emissaries of the EP with the Council. I was almost negotiating for 
the negotiator in one case' (Interview 50). Seen this way, civil society organisations which articulate public-and sometimes private-interests, can play a role in politicising issues in an otherwise closed policy-making system. Whilst CSOs can become drawn into the world of confidentiality in their quest for information, making it difficult for them to release information obtained in leaked documents, they can also stimulate public discussion of issues circulating in the 'Brussels bubble'.

\subsection{Speed as Important as Secrecy}

Even business organisations with extensive networks find it difficult to keep track of the pace of trilogue negotiations, particularly where this speeds up towards the end of a file. 'Too many, too quick', and 'we struggle to get the information' at the late stages (Interview 77), explained one. For the public affairs consultancies, with their established networks, however, 'we don't lack access to information. It's not my view that the external interests say that they lack information' (Interview 83).

It is clear that information-the currency of power in Brussels-about trilogues is available to civil society organisations with an office in Brussels. Nonetheless, complaints about the lack of transparency of trilogues indicate a limited ability to make interventions. Public affairs consultancies, with their extensive networks, seem to be most capable of acquiring information about the progress of trilogues, which is then passed on to a substantially business orientated clientele. For most civil society organisations, information becomes much more difficult to obtain the further down the pathway trilogues go, where EU institutions are intensively searching for consensus and external input becomes unhelpful. For some CSOs, information obtained during the trilogue process constrains their ability to politicise issues, on the basis that it is privileged information (Interview 44). These factors lean towards the view of the EP as a 'responsible' legislator. However, the 'information for analysis' thesis tends towards the view of the EP as a responsive legislator, sensitive to the information and perspectives which civil society organisations bring. Where civil society organisations are going in the same direction of travel as EU institutions, so they form a natural alliance, supporting the view of the Parliament as a responsive legislator, where information flows freely between the parties. NGOs are more likely to perform this role where EU institutions seek more stringent regulation, but business organisations too can have their own reasons for seeking more stringent regulation. Civil society organisations can then perform a role in lobbying the Council, and, occasionally, vice-versa, as foreseen in institutionalist accounts of the policy process.

\section{Conclusion}

Overall, we have traced how trilogues have become a politicised law-making institution, and shown how the
EP has become the main driver of this process, primarily through reliance upon a wide range of civil society organisations, and particularly NGOs. This has been our main contribution, providing empirical data which is otherwise scarce to find on the role of civil society organisations with trilogues, their relationships with EU institutions in the process, and whether there are any systematic biases in these relationships. The EP is able to assert itself viz. the Council of Ministers by using the 'noisy politics' of NGOs, and a wide range of NGOs are represented through the pluralisation of political parties in the EP in the trilogue process, such as the Greens or radical left parties.

Flows of information continue between EU lawmakers and organised interests during the pivotal trilogue process. Following the premises of politicisation, we show how civil society organisations have brought a growing salience to European governance, and an expansion of actors engaged in monitoring EU affairs. Trilogues themselves, by nature, lend themselves to politicisation, as an unstable and dynamic institution. The EP is the most sensitive to the implications of trilogues for democratic legitimacy, given its role as the people's tribune, and therefore a driving force in the politicization of trilogues.

\section{Acknowledgments}

The authors are grateful to two anonymous referees, and the Editorial team, for comments on earlier drafts of this article.

\section{Conflict of Interests}

The authors disclosed no conflicts of interest in the preparation of this manuscript

\section{References}

Albareda, A., \& Braun, C. (2019). Organizing transmission belts: The effect of organizational design on interest group access to EU policy-making. JCMS: Journal of Common Market Studies, 57(3), 468-485.

Andlovic, M., \& Lehmann, W. (2014). Interest group influence and inter-institutional power allocation in early second-reading agreements: A re-examination of aviation emissions trading. Journal of European Public Policy, 21(6), 802-821.

Baglioni, S., \& Hurrelmann, A. (2016). The Eurozone crisis and citizen engagement in EU affairs. West European Politics, 39(1), 104-124.

Brandsma, G. J. (2015). Co-decision after Lisbon: The politics of informal trilogues in European Union lawmaking. European Union Politics, 16(2), 300-19.

Brandsma, G. J. (2018). Transparency of EU informal trilogues through public feedback in the European Parliament: promise unfulfilled. Journal of European Public Policy, 2018, 1-20. https://doi.org/10.1080/ 
13501763.2018.1528295

Burns, C., Carter, N., Davies, G., \& Worsfold, N. (2013). Still saving the Earth? The European Parliament's environmental record. Environmental Politics, 22(6), 935-954.

Burson-Marsteller. (2009). A guide to effective lobbying in Europe. New York, NY: Burson-Marsteller.

Chalmers, A. (2019). Informational lobbying in the EU: Mechanisms of probity, dissembling, and transparency'. In D. Dialer \& M. Richter (Eds.), Lobbying in the European Union: Strategies, dynamics and trends. Cham: Springer.

Coen, D., \& Katsaitis, A. (2019). Legislative efficiency and political inclusiveness: The effect of procedures on interest group mobilization in the European Parliament. The Journal of Legislative Studies, 25(2), 278-294. https://doi.org/10.1080/13572334.2019.1603251

De Wilde, P., Leupold, A., \& Schmidtke, H. (2016). Introduction: The differentiated politicisation of European governance. West European Politics, 39(1), 3-22.

De Wilde, P., \& Zürn, M. (2012). Can the politicization of European integration be reversed? Journal of Common Market Studies, 50(1), 137-153.

Dionigi, M. (2019). Lobbying in the European Parliament: Who tips the scales? In D. Dialer \& M. Richter (Eds.), Lobbying in the European Union (pp. 133-148). Cham, Springer.

Dionigi, M., \& Koop, C. (2017). Investigation of informal trilogue negotiations since the Lisbon Treaty: Added value, lack of transparency and possible democratic deficit. Brussels: European Economic and Social Committee. Retrieved from https://www.eesc.europa. eu/sites/default/files/files/qe-01-17-783-en-n.pdf

Dür, A., \& De Bièvre, D. (2007). Inclusion without Influence: NGOs in European trade policy. Journal of Public Policy, 27(1), 79-101.

Dür, A., \& Mateo, G. (2014). Public opinion and interest group influence. Journal of European Public Policy, 21(8), 1199-1217.

Earnshaw, D., \& Judge, D. (2011). No simple dichotomies: Lobbyists and the European Parliament. Journal of Legislative Studies, 8(4), 61-79.

Emiliano De Capitani v. European Parliament 2018 Case T-540/15 (Luxembourg). Retrieved from https://eur-lex.europa.eu/legal-content/EN/TXT/ ?uri=CELEX\%3A62015TJ0540

EU Observer. (2014). Secret EU law-making: The triumph of the trilogue. EU Observer. Retrieved from http:// euobserver.com/investigations/123555

European Ombudsman. (2016). Decision of the European Ombudsman setting out proposals following her strategic inquiry OI/8/2015/JAS concerning the transparency of Trilogues. European Ombudsman. Retrieved from https://www.ombudsman. europa.eu/en/decision/en/69206

European Parliament. (2017a). Activity report on the ordinary legislative procedure (Activity Report No. DV $\backslash 1112171 E N)$. Brussels: European Parliament.
Retrieved from http://www.epgencms.europarl. europa.eu/cmsdata/upload/7c368f56-983b-431ea9fa-643d609f86b8/Activity-report-ordinarylegislative-procedure-2014-2016-en.pdf

European Parliament. (2017b). Interinstitutional negotiations for the adoption of EU legislation. European Parliament. Retrieved from http:// www.europarl.europa.eu/ordinary-legislativeprocedure/en/interinstitutional-negotiations.html

Greenwood, J. (2017). Interest representation in the European Union (4th ed.). Basingstoke: Palgrave Macmillan.

Greenwood, J., \& Roederer-Rynning, C. (2014). The 'Europeanization' of the Basel process: Financial harmonization between globalization and parliamentarization. Regulation \& Governance, 9(4), 325-338.

Hooghe, L., \& Marks, G. (2009). A postfunctionalist theory of European integration: From permissive consensus to constraining dissensus. British Journal of Political Science, 39(1), 1-23.

International New York Times. (2014). E.U. chided for lack of openness. International New York Times. Retrieved from http://news-business.vlex.com/vid/ chided-corruption-growing-distrust-507432674

Jacqué, J. P. (2009). Une vision réaliste de la procedure de codécision [A realistic viewpoint of the co-decision procedure]. In Mélanges en hommage à Georges Vandersanden [Essays in honour of Georges Vandersanded] (pp. 183-202). Brussels: Bruylant.

Judge, D. (1992). Predestined to save the earth: the environmental committee of the European Parliament. Environmental Politics, 1(4), 186-212.

Klüver, H. (2013). Lobbying in the European Union. Oxford: Oxford University Press.

Klüver, H., Braun, C., \& Beyers, J. (2015) Legislative lobbying in context: Towards a conceptual framework of interest group lobbying in the European Union. Journal of European Public Policy, 22(4), 447-461.

Kohler-Koch, B., \& Quittkat, C. (2013). De-mystification of participatory democracy: EU governance and civil society. Oxford: Oxford University Press.

Laloux, T., \& Delreux, T. (2018). How much do agents in trilogues deviate from their principals' instructions? Introducing a deviation index. Journal of European Public Policy, 25(7), 1049-1061.

Mahoney, J., \& Thelen, K. (Eds.). (2010). Explaining institutional change: Ambiguity, agency, and power. Cambridge: Cambridge University Press.

Mazey, S., \& Richardson, J. (1993). Lobbying in the European Community. Oxford: Oxford University Press.

Moe, T. M. (2005) Power and political institutions. Perspectives on Politics, 3(2), 215-233.

Peterson, J. (2001). The choice for EU theorists: Establishing a common framework for analysis. European Journal of Political Research, 39(3), 289-318.

Pollack, M. (1997). Representing diffuse interests in EC policymaking. Journal of European Public Policy, 4(4), 572-590. 
Rasmussen, M. (2014). The battle for influence: The politics of business lobbying in the European Parliament. Journal of Common Market Studies, 53(2), 365-382.

Ripoll Servent, A. (2013). Holding the European Parliament responsible: Policy shift in the data retention directive from consultation to codecision. Journal of European Public Policy, 20(7), 972-987.

Ripoll Servent, A. (2018). The European Parliament. Basingstoke: Palgrave Macmillan.

Rittberger, B., \& Schimmelfennig, F. (2006). Explaining the constitutionalization of the European Union. Journal of European Public Policy, 13(8), 1148-1167.

Roederer-Rynning, C., \& Greenwood, J. (2019). Beyond the 'internal game': Insiders meet outsiders in trilogues. Manuscript submitted for publication.

Rubow, C. (2003). Samtalen [the conversational interview]. In K. Hastrup (Ed.), Ind i verden: En grundbog $i$ antropologisk metode [Into the world: A textbook on anthropological method] (pp. 93-116). Copenhagen: Hans Reitzels Forlag.

Shackleton, M. (2000). The politics of codecision. Journal of Common Market Studies, 38(2), 325-342.

Shackleton, M., \& Raunio, T. (2003). Codecision since Amsterdam: A laboratory for institutional innovation and change. Journal of European Public Policy, 10(2), 171-187.

Spradley, J. P. (1979). The ethnographic interview. Belmont, CA: Wadsworth Cengage Learning.

Stie, A. E. (2012). Democratic decision-making in the EU: Technocracy in Disguise? Abingdon: Routledge.

Warleigh, A. (2000). The hustle: Citizenship practice, NGOs and 'policy coalitions' in the European Union: The case of auto-oil, drinking water and unit pricing. Journal of European Public Policy, 7(2), 229-243.

Waylen, G. (2014). Informal institutions, institutional change, and gender equality. Political Research Quarterly, 67(1), 212-223.

Weston, D. (2018). Europe agrees to $32 \%$ target. WindPower. Retrieved from https://www.windpower monthly.com/article/1484992/europe-agrees-32target

\section{About the Authors}

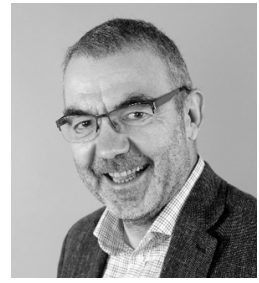

Justin Greenwood is Professor of European Public Policy at the Robert Gordon University, Aberdeen, UK, and a Visiting Professor at the College of Europe. His career-long research interest is interest representation in the European Union, with a 4th edition of a book bearing this name published by Palgrave Macmillan. This article reflects the focus of his recent work.

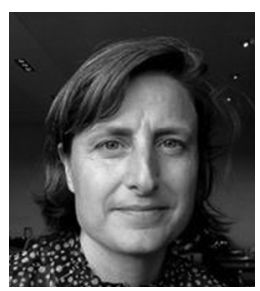

Christilla Roederer-Rynning is a Professor with special responsibilities in Comparative European Politics. She works on EU law-making, the Common Agricultural Policy, and trade policy. She coordinated 'The Parliamentarization of EU Politics', financed by the Danish Council for Independent Research. She co-edits Policy-making in the European Union (8th ed.), with Helen Wallace, Mark Pollack, and Alasadair Young (Oxford University Press). 


\section{COGITATIO}

\section{Appendix}

All interviews conducted in Brussels, unless otherwise indicated.

Interview numbers reflect the assigned numbers from our interview database.

Interview 84 with Mr. Emilio De Capitani, 23.01.2019. Mr. De Capitani was happy to be quoted and attributed.

Interview 60 with a national trade union, 6.12.2017.

Interview 37 with an MEP Assistant, 13.2.2018.

Interview 63 with a producer association, 12.1.2018.

Interview 44 with an NGO, 25.9.2017.

Interview 43 with an NGO, 25.9.2017.

Interview 12 with a Permanent Representation of a member state, 16.1.2018.

Interview 70 with a producer association, 6.6.2018.

Interview 68 with a producer association, 5.4.2018.

Interview 44 with an NGO, 25.9.2017.

Interview 12 with a producer association, 7.6.2018.

Interview 51 with an NGO, 6.10.2017.

Interview 74 with a producer association, 7.6.2018.

Interview 51 with an NGO, 6.10.2017.

Interview 50 with an NGO, 29.9.2017.

Interview 77 with a producer association, 8.6.2018.

Interview 83 with a Public Affairs consultancy, 6.6.2018. 